\title{
An investigation into the teaching of information literacy skills by teachers in New Zealand secondary schools.
}

\author{
Elizabeth Probert \\ Lecturer \\ The University of Auckland \\ Faculty of Education \\ New Zealand
}

\begin{abstract}
There is very little research looking at how much teachers from any country actually know about information literacy and at how they develop information literacy skills with their students. This contrasts research in recent years which focuses on the influence that school libraries, teacher librarians and/or library media specialists have on student learning. For some time international government and educational bodies, including New Zealand, have recognised that all citizens need skills and processes to enable them to become information literate. This paper reports on findings from a research project which investigated the understanding, knowledge and teaching of information literacy processes of secondary teachers from five urban co-educational state secondary schools.
\end{abstract}

\section{Introduction}

This paper describes a research project which investigated the extent to which secondary teachers in five schools in Auckland, New Zealand, understand the concept of information literacy, the extent to which these teachers explicitly teach information literacy skills and the extent to which this influences the choice of National Certificate of Educational Achievement (NCEA) achievement standards taught in their classes.

\section{Background}

The development of information literate students is seen as important in New Zealand education just as it is elsewhere in the world, with many international governments and educational bodies agreeing that all citizens need skills and processes to enable them to become information literate. (American Library Association 1989; Bundy 1998; Doyle 1999; Langford 1999; Todd 2004). As far back as 1993 the New Zealand Curriculum Framework (Ministry of Education, 1993) stated that all students should develop skills enabling them to develop 'the ability to locate, evaluate, manipulate, manage and communicate information from different sources’. (p18).

This emphasis is also seen in the 2002 introduction of The National Certificate of Educational Achievement (NCEA), New Zealand's national qualification for secondary school learners aged from 15-17 years. NCEA includes internally assessed achievement standards, a number of which, from most subject areas, require the use of some or all of a research process (New Zealand Qualifications Authority 2005). Another initiative, Digital horizons: Learning through ICT (2002), the New Zealand Ministry of Education's strategy for Information and Communication Technology (ICT) also emphasises the need for students to develop information literacy so that 'they are equipped with skills enabling them to take advantage of the opportunities offered by the use of ICT' (Ministry of Education 2003, p32). 
It could have been expected therefore that with such developments, there would be some assessment of New Zealand secondary teachers' understanding of and competency to teach information literacy. Instead it appears to have been assumed, as others in New Zealand and elsewhere have found, (Moore 2002; O’Connell \& Henri 1997; Henri 2001; Wilson 1997) that teachers are somehow already equipped to teach information literacy processes. It should also be noted that most New Zealand secondary schools do not employ trained teacher librarians although most employ one or more school librarians, as did the schools participating in this research project ${ }^{1 .}$

There have been warnings in New Zealand that all might not be well as seen in the results of the New Zealand National Education Monitoring Project (NEMP) Information skills: Assessment Results (Flockton \& Crooks 2002) which reported that while pre-secondary age students (8 years and 12 years) might be able to find information they were not very skilled at using it. This is an indication that students arriving at secondary school may not have well developed information literacy skills. Hipkins (2005), currently investigating 'research as a student learning activity' in six Wellington, New Zealand secondary schools reports that students felt they had not been taught the skills they needed to carry out their own research projects and also observed that much of the research appeared to be mainly information retrieval and repackaging.

The Education Review Office (ERO), the government department which reviews and reports publicly on the quality of education in all New Zealand schools and early childhood education services recently carried out, with 400 schools, an evaluation of the information landscape, a key aspect of which is 'information literacy which is a broad concept, embracing the skills, knowledge, attitudes and values required to function effectively in the information landscape' (ERO 2005). The evaluation was informed by the document The school library and learning in the information landscape: Guidelines for New Zealand schools (Ministry of Education \& The National Library of New Zealand 2002). The report, Student learning in the information landscape (ERO, 2005) concluded that many primary schools and most secondary schools are not addressing student development of information literacy skills stating that 'Information literacy was a particularly weak area' and that 'there were few examples a school-wide, integrated approach using an information process model.' (p2). It was also noted that while half the school libraries visited were effectively set up to support information literacy development, the links between the library and the school's teaching and learning programmes were not effective. This was particularly so in secondary schools. There were also ineffective and unclear links between the school library and the role of ICT in the classroom.

The recently published report, E-learning in secondary schools (Education Review Office, 2005) also with a focus on student information literacy development, pointed out the need for 'improving assessment, monitoring and analysis of (...) information literacy skills and abilities' (p2). The evaluation included classroom observations, reviews of school documentation and interviews with students, teachers, parents, principals, teachers with library responsibility and ICT coordinators.

In view of these concerns, it seems timely to investigate more closely secondary teachers' understanding, knowledge and teaching of information literacy processes and the extent to which these influence NCEA achievement standards to be included in their teaching programmes. 


\section{The project}

This research study aimed to answer three questions concerning secondary teachers in Auckland schools:

1 To what extent do teachers understand the concept of information literacy?

2 To what extent do teachers explicitly teach information literacy skills?

3. To what extent does this influence the choice of those NCEA achievement standards that require the use of an information process?

Qualitative and quantitative methods were employed to collect data using a questionnaire and focus groups. The questionnaire included both Likert and frequency scales (Neuman, 2003) to measure teachers' opinions and perceptions of what they believe and practice and also included a number of open ended questions (Creswell 2002). Respondents were given the option to join focus group discussions to allow for clarification of questionnaire responses.

The research began with a pilot project involving staff of one Auckland urban secondary school only, in order to gauge the value of further investigation with a larger number of schools. Respondents there were also asked to provide feedback on the design of the questionnaire. The response rate of questionnaires for the first project was $27.5 \%(n=33)$. Analysis of the data from this project revealed that most respondents did not have a clear understanding of the concept of information literacy and were not on the whole developing their students' information literacy skills although all those teaching senior students were also teaching NCEA achievement standards involving the research process. Respondents also supplied useful feedback about the questionnaire design as did colleagues, both national and international, who were asked for comment and suggestions.

In the light of these findings it was decided to investigate the situation at four other Auckland state co-educational secondary schools randomly selected within four bands sorted according to decile level [see Table 1] and roll size which was limited to 1000 to avoid schools with large staff numbers. Suggested changes were made to the design of the questionnaire which was then distributed to the staff of the four selected schools once the permission of each principal had been obtained. Questionnaires were distributed one week and collected the following week. Data from the questionnaires was entered into M/S Excel, frequencies calculated and statements coded and categorised in order to supply evidence with which to answer the research questions.

Table 1

Population from which sample was chosen

\begin{tabular}{|c|c|}
\hline Decile* band & 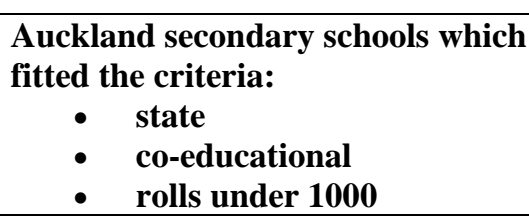 \\
\hline Decile 1-2 & 3 \\
\hline Decile 3-5 & 3 \\
\hline
\end{tabular}




\begin{tabular}{|l|l|}
\hline Decile 6-8 & 4 \\
\hline Decile 9-10 & 3 \\
\hline Total & $\mathbf{1 3}$ \\
\hline
\end{tabular}

The questionnaire return rate was not high with 23.7\% ( $n=69)$ returned from the 290 distributed to the four schools although most subject areas were represented. Once the questionnaire results had been analysed, respondents who indicated they were willing to participate in focus groups were then contacted, dates set for meetings and discussions held. Analysis of those discussions was added to the findings from the questionnaires.

\section{Results}

It was found that the findings from the four schools were very similar despite decile differences and so have been combined for the purposes of this paper.

The American Library Association (1989) definition of information literacy

To be information literate, a person must be able to recognize when information is needed and have the ability to locate, evaluate and use effectively the needed information.....information literate people are those who have learned how to learn.

was used for the project as this description is widely accepted in official New Zealand educational circles, has been adopted by the School Library Association of New Zealand Aotearoa (SLANZA) and is the definition used by the Education Review Office (ERO) when carrying out their evaluation of the Information Landscape. In addition, it is used in the document School libraries and learning in the information landscape (2002) which also notes with examples, that definitions of information literacy continue to evolve.

\section{The extent of teachers' understanding of the concept of information literacy}

The term 'concept' for the purposes of this research involved respondents demonstrating a clear understanding of the attributes of an information literate person and an understanding of the process itself. Data from responses to several questions were used to gauge teacher understanding, including one question asking respondents to describe an information literate person.

It was clear from their descriptions of an information literate person as summarised in Fig 1, that few teachers in this survey had a clear understanding of the concept of information literacy as defined for this project. It was also evident that a number of teachers confused Information and Communication Technologies (ICT) with information literacy. 


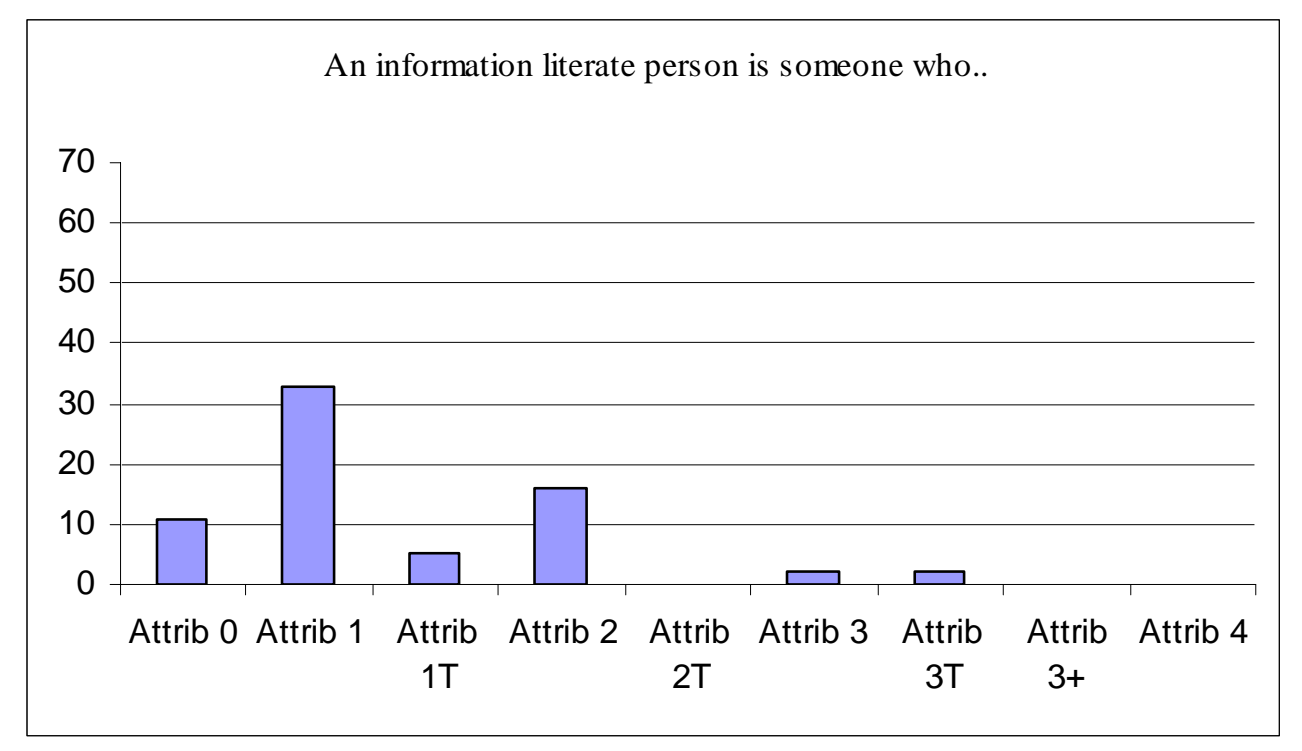

Fig 1. Respondents' understanding of the attributes of an information literate person when matched to ALA definition

Explanation of chart:

$0=$ no attributes of the accepted definition

1 = one or two attributes

$1 \mathrm{~T}=$ one or two attributes but related only to computers or WWW

$2=$ three attributes

$2 \mathrm{~T}=$ three attributes but related only to computers or WWW

$2+=$ three or four attributes but not including

3 = all attributes from ALA definition

4 =all ALA attributes plus other aspects from The school library and learning in the information landscape: Guidelines for New Zealand schools (2002).

The descriptions were also matched to Bruce's (1998) seven conceptions of information literacy (table 2). It can be seen that almost half the respondents from the four schools described or implied that being information literate involved a process, a result also noted by Moore (2005) while a quarter understood information literacy as finding resources and the remainder linked it with information and communications technologies. There were no replies which matched any of the other four conceptions. The majority of teachers though did demonstrate some understanding of aspects of information literacy in that most saw information skills as encompassing more than just library skills, as concerned with a wider range of resources than just those located in libraries and as involving more than the use of ICT.

Table 2

Respondents' understanding of an information literate person according to Bruce (1998).

\begin{tabular}{|l|l|l|}
\hline \multicolumn{2}{|l|}{ Conceptions of an information literate person (Bruce, 1998) } & $\begin{array}{l}\text { Respondents } \\
\mathrm{N}=69\end{array}$ \\
\hline 1 & $\begin{array}{l}\text { The information technology conception. Information literacy is } \\
\text { seen as using technology (IT) for information retrieval and } \\
\text { communication. }\end{array}$ & 8 \\
\hline 2 & $\begin{array}{l}\text { The information sources conception. Information literacy is } \\
\text { seen as finding information. }\end{array}$ & 17 \\
\hline
\end{tabular}




\begin{tabular}{|l|l|l|}
\hline 3 & $\begin{array}{l}\text { The information process conception. Information literacy is seen } \\
\text { as executing a process }\end{array}$ & 33 \\
\hline 4 & $\begin{array}{l}\text { The information control conception. Information literacy is seen } \\
\text { as controlling information. }\end{array}$ & 0 \\
\hline 5 & $\begin{array}{l}\text { The knowledge construction conception. Information literacy is } \\
\text { seen as building up personal knowledge base in a new area of } \\
\text { interest. }\end{array}$ & 0 \\
\hline 6 & $\begin{array}{l}\text { The knowledge extension conception. Information literacy is } \\
\text { seen as working with knowledge and personal perspectives } \\
\text { adopted in such a way that new insights are gained. }\end{array}$ & 0 \\
\hline 7 & $\begin{array}{l}\text { The wisdom conception. Information literacy is seen as using } \\
\text { information wisely for the benefit of others. }\end{array}$ & 0 \\
\hline & \begin{tabular}{l} 
No response \\
\hline
\end{tabular} & 11 \\
\hline
\end{tabular}

It was interesting that while the majority of teachers described or implied the involvement of a process and later indicated they were familiar with the way the information process could be broken down into stages (see Fig 2) only three were able to provide six or seven identifiable stages of an ordered process such as deciding/defining, locating, using, processing, analysing, presenting, evaluating. (see Fig 3). Again, while some indicated they used an information processing model with their students, only two supplied the name of a recognised model such as the New Zealand model Action Learning (Gawith 1989). These findings were supported by several focus group participants who said they were not sure what was meant by the terms 'information literacy process', 'stages' or 'model', although the names of models such as The resource cycle (McKenzie 2005) and Big6 (Eisenberg \& Berkowitz 2005) were included in the question to aid clarification.

Fig 2

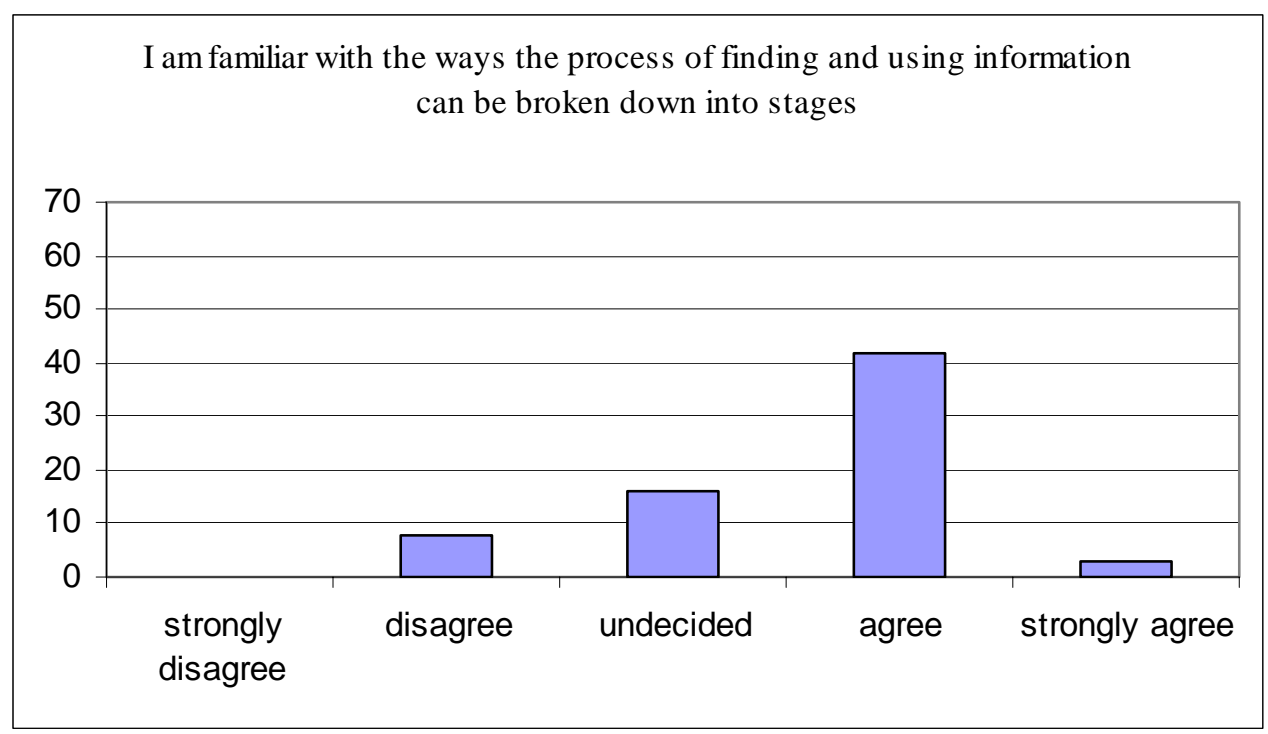


Fig 2. Teachers' responses when asked if they were familiar with the stages of information processing

Fig 3

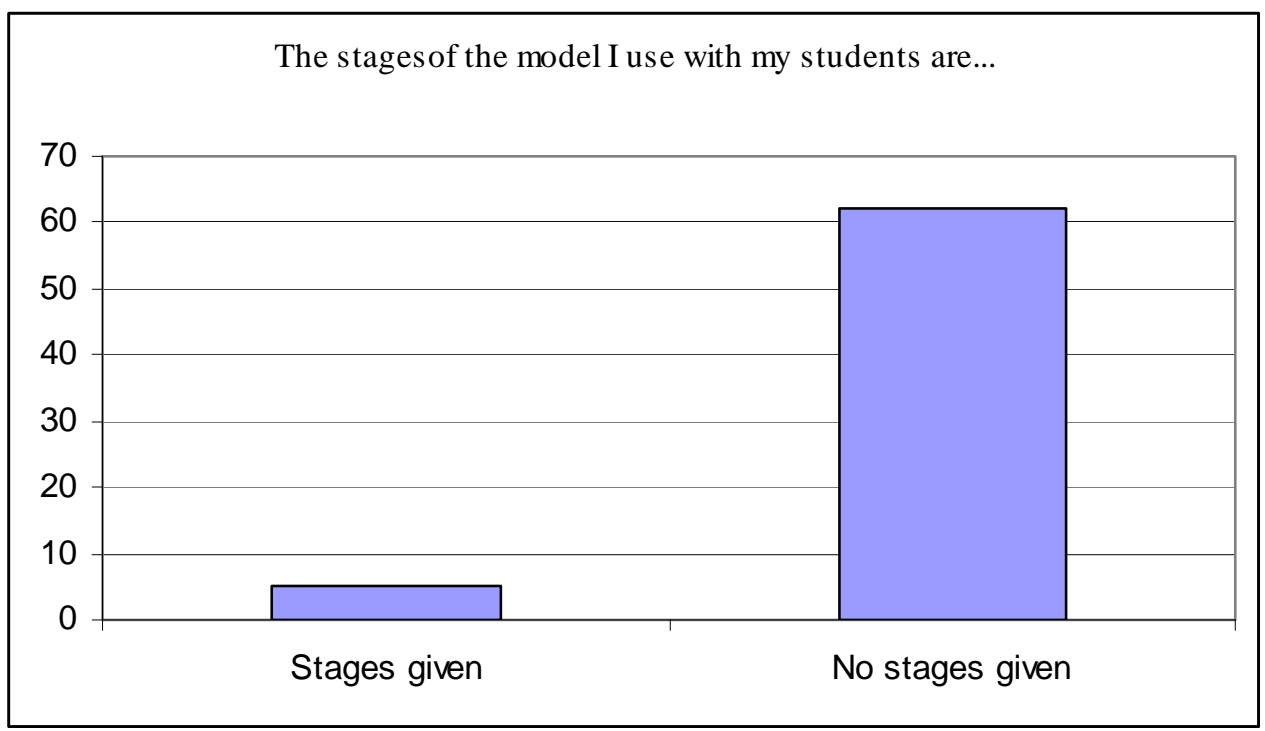

Fig 3. Summary of teachers' responses when asked to name the stages of the model they use with their students.

The extent to which teachers explicitly teach information literacy skills:

While some teachers were uncertain that it would be helpful to have a common method for completing school research assignments or a school wide information literacy development plan, many agreed these would be helpful and that it would also be helpful if they were provided with strategies for teaching information skills (see Fig 4). There was a higher level of uncertainty as to whether respondents expected students entering secondary school to already have good information skills (see Fig 5) and half the teachers rarely or never checked the skill levels of their classes at the start of each year while 26 did so sometimes or often. No one indicated that this was always done. Even so, two thirds did not see such skills as developing without being explicitly taught while a third were either undecided or agreed that such skills develop naturally without teaching.

Fig 4 


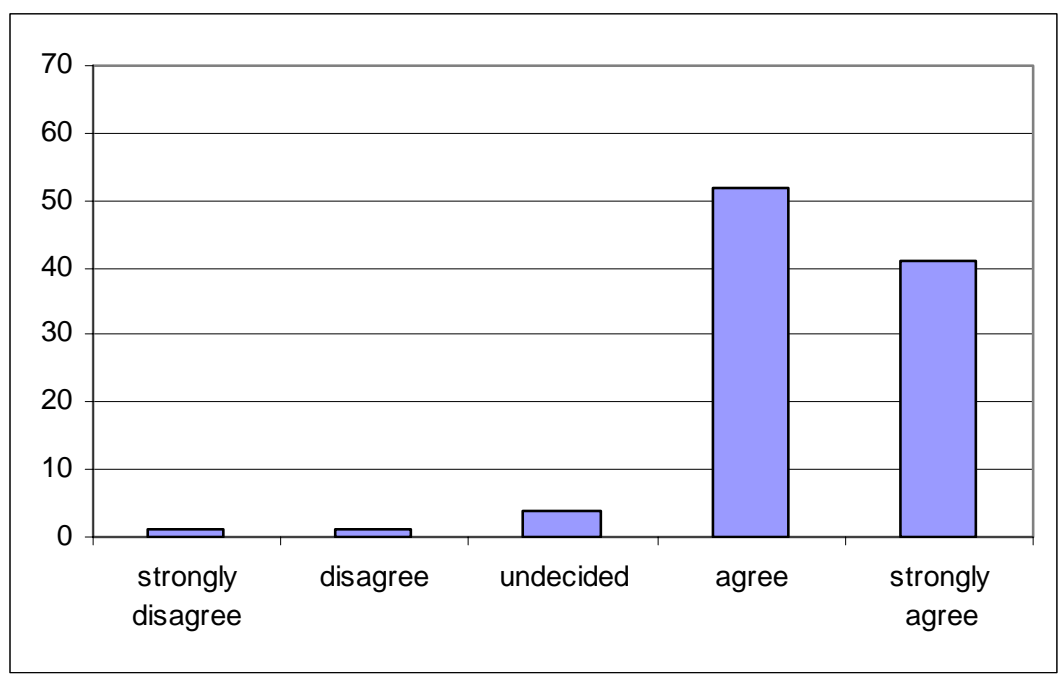

Fig 4. Summary of responses to the statement that if it would be helpful if teachers were supplied with strategies for teaching information skills.

Fig 5

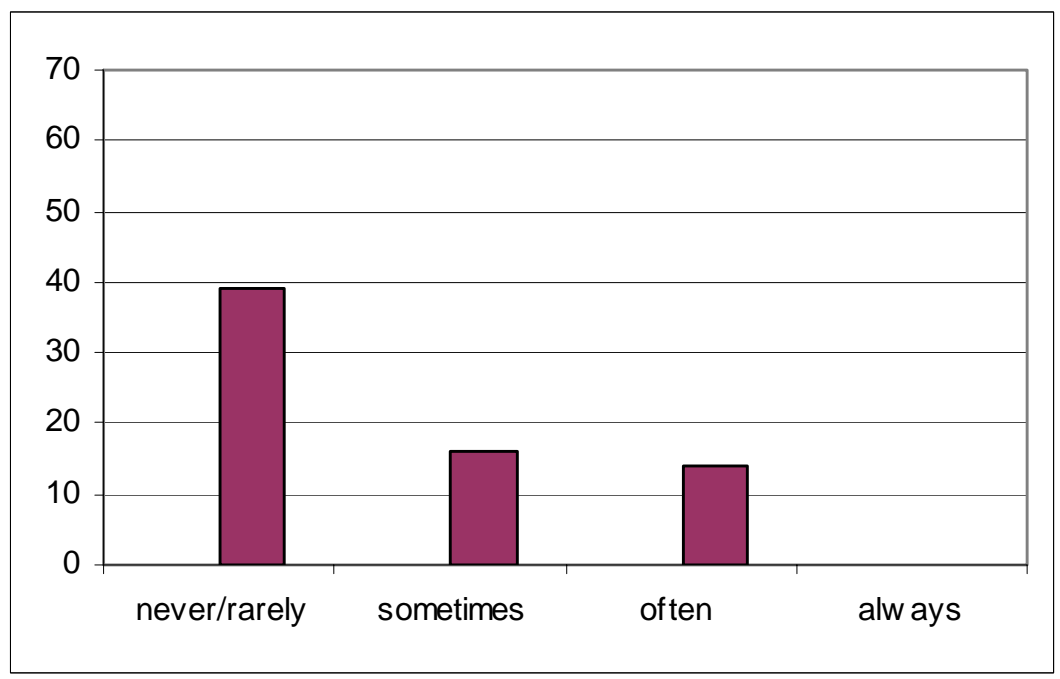

Fig 5. Summary of teachers' responses to the statement that they checked the information skills levels of their classes at the start of each year.

When asked about modelling various skills for their students, the skill most often modelled was brainstorming, followed by finding information in books, using online resources and presenting information. However over one third of teachers never or rarely modelled any of the skills asked about. During the follow up focus group discussions, several teachers said they either took it for granted that students had these skills or felt it was not their responsibility to develop the skills. Several teachers expressed annoyance that they had to teach their students how to take notes as no one else seemed to. Another said that 'students see what they learn in one subject as totally separate from other subjects'. 


\section{The extent to which knowledge of information literacy influenced choice of NCEA achievement standards:}

Nearly a third of teachers indicated they had participated in professional development about teaching information skills and a variety of professional development was described but only two teachers described anything that recognisably concerned information literacy and which would help with research activities in NCEA achievement standards. Other courses included ICT conferences, literacy training and ESOL (English Speakers of Other Languages) courses.

According to the responses from the questionnaire, all teachers of senior classes, covering most subject areas, taught NCEA internally assessed achievement standards which involve all or some of a research process. This was surprising given that so few seemed familiar with an information process or with the particular skills their students might need. Several teachers from one school replied that as 'all resources were included there was no need to carry out research at all' and another stated that their school's NCEA results of those achievement standards 'don't stand out as having poorer results than other achievement standards - actually we got bad results from another kind of achievement standard, not from research ones'.

\section{Discussion and conclusions}

From these findings it appears that while teachers on the whole seem to be aware of information skills and of the need for them to be explicitly taught, this belief is not followed through in practice. The very large proportion of teachers who thought it would be helpful if they were provided with a variety of strategies for developing such skills appears to indicate that many recognise the need for professional development in this area. This result from the questionnaire was upheld during focus group discussions with teachers, all of whom emphasised the need to for their schools have some form of school wide research method and to be provided with strategies for skill development.

It is of concern that so many teachers of senior secondary students teach NCEA achievement standards involving information processing and yet so few appear to have much knowledge of information literacy or to explicitly teach information skills with their students. It would therefore be useful to examine the actual assessment criteria for NCEA achievement standards and it would also be interesting to discover how NCEA assessment criteria for research are interpreted and assessed by teachers and to reappraise if necessary our current criteria. Hipkins (2005) provides an interesting comparison of descriptive indicators using the New Zealand NCEA Geography 1.5 Carry out and present directed geographic research achievement standard and the much more detailed descriptive indicators of performance taken from the draft American Equipped For the Future (EFF) standards.

There also appears to be some problems with the term 'information literacy' itself. Almost all focus group participants stated that they were not familiar with the term, some aligning it with ICT and some with literacy 'or reading of some sort'. Although questions in the questionnaire were written to include the term 'research' along with 'information literacy', a number of teachers said they do not see information literacy as having anything to do with carrying out a research process. This is an area which certainly needs to be addressed, at least in New Zealand and possibly in other countries. 
An interesting aspect from the findings in the pilot project arose from the fact that the school involved had employed a teacher librarian for some years previously although the position had not been filled after 2002 when the incumbent left. However despite this influence and the fact that a number of staff had received professional development with an information literacy focus in previous years, few teachers at this school appeared to have a clear understanding of information literacy. Little of this training appears to have 'stuck'. While allowance has to be made for staff turnover, this finding could suggest that for information literacy development in a school to be effective, someone needs to be responsible for ongoing, continuous development. (Moore \& Trebilcock 2003, p175). None of the four schools in the second project employ or used to employ a teacher librarian.

There is an indication from these findings of the need for a larger investigation of secondary teachers' information skills which could perhaps include the influence of the school library and also investigate just how teachers are teaching those skills they say they are modelling. An investigation of the efficacy over time of information literacy training would also be helpful.

It would also be very useful for New Zealand schools to discover how well secondary teachers in Australian and in other countries understand the concept of information literacy, how they develop the skills with their students and the role played in the training of classroom teachers by teacher librarians. The New Zealand Post Primary Teachers Association (PPTA) recently adopted recommendations put forward by the School Library Association of New Zealand Aotearoa (SLANZA) which included the employment of teacher librarians in secondary schools. Specific evidence of the worth of teacher librarians would be of great value to the SLANZA cause.

It can concluded then that possibly a large proportion of New Zealand secondary teachers may not have a good understanding of information literacy and that many do not explicitly teach information skills although they teach NCEA achievement standards involving information processing. Henri's (2004) statement that 'teachers must be information literate and model this to each other and to students' must be heard and heeded with appropriate action taken, especially in New Zealand schools. Several conditions will have to be met however if this is to be achieved. Tertiary teacher training institutions need to include information literacy as an integral part of their courses and all schools need to appoint teachers who have the responsibility for planning and developing school-wide information literacy across the curriculum. Also secondary schools in particular must recognise the need for professional development so that all New Zealand teachers, together with trained school library teams, can better fulfil the aims of the New Zealand Curriculum Framework by contributing to the development of information literate students, able to participate fully in their rapidly changing world.

\section{Note}

${ }^{1}$ Teacher librarians: Few NZ schools employ teachers who have additional qualifications as teacher librarians. Most secondary schools though do employ school librarians although not all are necessarily trained librarians. While the schools participating in this project did not employ teacher librarians, they all employed school librarians although it is not known whether or not they were qualified librarians. Also in many schools, a teacher may be designated as the teacher with library responsibility (TLR) although that person may have had no specialised training in managing school 
libraries or developing information literacy across the curriculum. Many schools have a school library team which may include the school librarian/s, the teacher with library responsibility (TLR) and, often in primary schools, the principal.

\section{References}

American Library Association, (1989). Viewed July 12, 2005, http://www.ala.org

Bruce, C. (1998). The phenomenon of information literacy. Higher Education Research and Development, 17(1), 2543.

Bundy, A. (1998). Information literacy: the key competency for the $21^{\text {st }}$ century. Viewed 19 October, 2004, http://www.library.unisa.edu.au/about/papers/inlit21.htm

Creswell, J. (2003). Research design: Qualitative and quantitative approaches. ( ${ }^{\mathrm{nd}}$ Ed.). Thousand Oaks, California: Sage.

Doyle, C. (199). Information literacy in an information society. In K. Haycock (Ed). Foundations for effective school library media programs. (pp97-100). Englewood, CO: Libraries Unlimited.

Education Review Office, (2005). Ministry of Education decile ratings. Viewed 12 November 2005, http://www.ero.govt.nz/reports/MoEInfo.htm

Education Review Office, (2005). Student learning in the information landscape. Wellington: Education Review Office.

Education Review Office, (2005). ERO school and early childhood education reports. Viewed 12 November 2005, http://www.ero.govt.nz/reports/Indexsearch.htm

Education Review Office (2005). E-learning in secondary schools. Wellington: Education Review Office.

Eisenberg, M \& Berkowitz R., (2005) .The Big 6: An information literacy model. Viewed 22 November 2005, http://www.big6.com/

Flockton, L. \& Crooks, T. (2002).. Information skills: Assessment results 2001. Dunedin: Educational Assessment Research Unit, University of Otago.

Gawith, G. (1988). Action learning. Auckland: Longman Paul

Henri, J. (2001). Thinking and informing: A reality check on class teachers and teacher librarians. Inspiring connections: Learning, libraries \& literacy: proceedings of the International Association of School Librianship, IASL, Auckland, pp 119-128.

Henri, J. (2004),. Building and information literate school community: Putting teachers first. Constructing communities of literacy and learning. Proceedings of the Australia School Library Online Conference. ASLA. Pp86-90.

Hipkins, R.( 2005). Students' experience of researching in different subjects. set: Research information for teachers, $1,18-22$.

Hipkins, R. (2005). Information literacy and student research. . set: Research information for teachers, 2, 27-31.

Langford, L (1999). Information literacy? Seeking clarity. In J Henri \& K Bonanno (eds.). The information literate school community. (pp. 43-54). Wagga Wagga: Centre for information studies, Charles Sturt University.

McKenzie, J. (2005). The research cycle. Viewed 22 November 2005, http://questioning.org/rcycle.html

Ministry of Education \& National Library of New Zealand. (2002). The school library and learning in the information landscape: Guidelines for New Zealand schools. Wellington: Learning Media 
Ministry of Education (1993). New Zealand Curriculum Framework. Wellington: Learning Media.

Ministry of Education , (2002) Digital horizons: Learning through ICT. Wellington: Ministry of Education.

Moore, P. (2002). Information literacy: What's it all about? Wellington: New Zealand Council for Educational Research.

Moore. P \& Trebilcock. M. (2003). The school library team: What does it do to influence teaching and learning? Auckland: Auckland College of Education.

Moore, P. (2005). Information literacy in the New Zealand education sector. Paper presented at Asia and Pacific Seminar-Workshop on Educational Technology. 2005. Lifelong learning and information literacy. The Seventh Programming Cycle of APEID Activites. Asia and the Pacific Programme of Educatonal Innovation for Development. (APEID), Tokyo Gakugei University, 5-9 September, 2005. Tokyo, Japan.

Neuman, W. (2000). Social research methods: Qualitative and quantitative approaches. (4 ${ }^{\text {th }}$ ed.). Boston: Allyn and Bacon.

New Zealand Qualifications Authority, (2005). National standards. Viewed 12 November 2005, http://www.nzqa.govt.nz/ncea/assessment/

O’Connell, J \& Henri, J. (1997). Information literacy: Teachers’ perspectives of the information process. In L Lighthall \& K Haycock Information rich but knowledge poor: Emerging issues for schools and libraries worldwide. Seattle, WA: IASL. 125-136.

Todd, R. (2004). Student learning through Ohio school libraries: The Ohio research study. Viewed 19 September 2005, http://www.oelma.org/studentlearning/default.asp

Wilson, K. (1997). Information skills: The reflections and perceptions of student teachers and related professionals. In L Lighthall \& K Haycock Information rich but knowledge poor: Emerging issues for schools and libraries worldwide. Seattle, WA: IASL. 63-74.

\section{Biographical note}

Elizabeth Probert is a trained teacher librarian who taught at a large Auckland secondary school before taking up her present position as lecturer at the Faculty of Education, the University of Auckland.

She has directed one the first three-year Ministry of Education ICT Strategy contracts to provide ICT PD to the staff of a cluster of six local schools and has presented workshops and seminars at conferences here and overseas. She is a past president of the School Library Association of New Zealand Aotearoa (SLANZA).

\section{Statement of originality}

This statement certifies that the following paper is based upon original research undertaken by the author and that the paper was conceived and written by the author alone. All information and ideas from others is referenced.

$$
\begin{aligned}
& \text { Gxpsent } \\
& \text { Elizabeth Probert }
\end{aligned}
$$


Reproduced with permission of the copyright owner. Further reproduction prohibited without permission. 